\title{
KISAH PANJI PADA RELIEF CANDI SEBAGAI INSPIRASI PENCIPTAAN FILM
}

\author{
Philipus Nugroho Hari Wibowo \\ Institut Seni Indonesia Yogyakarta
}

\begin{abstract}
Abstrak: Penciptaan karya film ini terinspirasi relief Panji pada Candi Kendalisodo di Gunung Penanggungan, Jawa Timur. Panji merupakan cerita asli Indonesia yang digubah dalam berbagai versi sastra: kidung, lisan, juga relief pada candi. Dengan metode penciptaan Road Movie dan Theory of Adaptation Hutcheon, kisah Panji diadaptasi dari relief menjadi sekumpulan peristiwa berbentuk film perjalanan. Penciptaan ini menghasilkan sebuah film pendek berdurasi 15 menit dengan judul "Melacak yang Tersurat".
\end{abstract}

Kata Kunci : Cerita Panji, Relief, Kendalisodo, Film Perjalanan, Adaptasi

\begin{abstract}
The creation process behind this movie is inspired by the Tale of Panji carved in Candi Kendalisodo's stone wall at Gunung Penanggungan, East Java. Panji is one of Indonesian original stories and has been told in various literary forms: hymn, oral story, and also carved into temple. With the Road Movie creation method and Hutcheon's Theory of Adaptation, the Tale of Panji is adapted from stone carvings to a sequence of events told in a road movie. This creation produces a short movie in 15 minutes duration titled "Melacak yang Tersurat" (Tracking the Facts).
\end{abstract}

Key words : Tale of Panji, Stone Carving, Kendalisodo, Road Movie, Adaptation

\section{Pendahuluan}

Banyak topik yang menarik untuk dijadikan ide dalam penciptaan karya film, dari hal yang paling sederhana sampai hal yang luar biasa. Ide cerita bisa lahir dari manapun, dari berbagai pengalaman maupun pengamatan pencipta yang kemudian diramu dengan imajinasi, baik dari kehidupan sehari-hari, melihat film hingga mengadaptasi berbagai teks menjadi teks baru. Sejauh ini proses adaptasi sebuah film banyak dilakukan dari sumber-sumber teks sastra seperti novel, cerpen, maupun naskah panggung, bahkan beberapa film yang diangap sukses baik secara finansial maupun popuaritas diproduksi ulang Relief-relief naratif pada situs candi bisa menjadi alternatif ide untuk diadaptasi menjadi karya film, mengingat belum banyaknya cerita film yang mengambil candi sebagai ide dasarnya, terutama relief candi.
Relief pada candi-candi (Hindu Buddha) di Jawa terdapat pada kaki candi dibagian yang strategis sehingga mudah untuk diamati oleh pengunjung. Selain memperindah bangunan candi (relief hiasan), relief juga menggambarkan cerita (relief cerita) keagamaan dan pendidikan, namun ada juga yang latar belakang ceritanya adalah kisah romantis atau bahkan suatu cerita yang belum dikenal (Munandar, 2004).

Cerita Panji merupakan salah satu kisah yang dipahatkan di dinding candi seperti halnya Ramayana, Arjunawiwaha, Sudhamala, dan juga Sri Tanjung. Hal ini menjadi menarik, karena sejauh ini cerita Panji popular melalui teks sastra kidung maupun tari dan pertunjukan.

Panji dipandang sebagai cerita asli Indonesia yang merupakan satu di antara legenda-legenda lokal yang paling terkenal di Asia Tenggara. Di Jawa, Panji dianggap 
sebagai ksatria keturunan Pandawa, pahlawan dari Mahabarata. Di daratan Asia Tenggara Panji lebih dikenal sebagai Inao, kesatria Budhis yang akan datang kembali di akhir zaman (Brandon, 2003). Pada masa Majapahit, Cerita Panji digubah dalam berbagai versi sastra (kidung, lisan) cerita panji juga dipahatkan dalam bentuk relief pada candi-candi. Kieven (2014a) menyebutkan dalam makalahnya pada Seminar Naskah Panji yang ia tuliskan berdasar buku Following the cap-figures in Majapahit temple reliefs (Kieven, 2014b) bahwa ia menemukan adanya perbedaan antara medium gambar dan medium sastra: Dalam cerita Panji sebagai sastra sering muncul adegan peperangan, sedangkan dalam gambar relief, Panji sama sekali tidak bertindak sebagai prajurit yang berperang (Kieven, 2014c). Lebih lanjut Kieven menjelaskan Kisah Panji, baik dalam bentuk sastra maupun dalam bentuk visual, punya konotasi kerakyatan: walaupun berstatus kaum bangsawan, Panji dan Candrakirana bersikap sederhana seperti rakyat biasa. Misalnya saat mereka berkelana di daerah pedesaan, dalam relief mereka digambarkan berpakaian sederhana dengan sedikit hiasan saja, lingkungan juga digambarkan secara minimalistis dan tidak mewah (Kieven, 2014c).

Menurut Kapustakaan Jawi, cerita Panji telah ada sekitar abad ke-15. Pada masa itu bahasa Jawa-Tengahan telah menjadi bahasa pergaulan sehari-hari di wilayah Majapahit. Akan tetapi jika dilihat secara internal, Cerita Panji lebih mengetengahkan suatu kondisi masyarakat pada masa kejayaan Kediri. Ada suatu anggapan bahwa tokoh Panji adalah sebuah manifestasi dari raja Kediri masa itu, Kameswara II yang berkuasa sekitar abad ke-12 (Poerbatjaraka, 1985). Cerita Panji secara ringkas menceritakan tentang kisah percintaan antara putera mahkota Kerajaan Koripan (Raden Panji) dengan Puteri Daha
(Raden Galuh atau Candrakirana). Sejak kecil keduanya telah ditunangkan, namun ketika Raden Panji menginjak dewasa, ia tergoda dengan seorang perempuan yang ditemuinya ketika sedang berburu. Raden Panji kemudian membawanya pulang. Mengetahui hal tersebut ibunya sangat marah, apalagi ia teringat dengan pertunangan yang telah disepakati dengan raja Daha. Ia kemudian berupaya untuk menyingkirkan perempuan tersebut.

Terlanjur terikat janji pada masa lalu, maka pernikahan Raden Panji dan Putri Candrakirana tetap harus dilangsungkan. Saat perkawinan akan direncanakan dan kedua calon mempelai dipertemukan. Putri Candrakirana mendadak hilang bersama para pengasuhnya. Kejadian inilah yang kemudian menghadirkan kisah demi kisah pengembaraan yang kemudian berkembang pada penaklukan-penaklukan wilayah. Raden Panji dan Putri Candrakirana dalam penggembaraannya, selalu berganti-ganti nama. Keduanya melakukan penyamaran sebagai ksatria dan seringkali menjadi pahlawan di daerah-daerah yang dilewatinya. Putri Candrakirana pada suatu waktu bahkan berubah menjadi ksatria yang betul-betul seperti lelaki. Pada beberapa kesempatan keduanya sebetulnya dipertemukan di suatu tempat, akan tetapi tidak saling mengenali. Setelah sekian waktu mengalami cobaan dan ujian, Raden Panji dan Putri Candrakirana akhirnya dipertemukan. Pesta pernikahanpun segera digelar, selanjutnya keduanya menjadi raja dan permaisuri yang memerintah kerajaan dengan arif dan bijaksana.

Inti dari cerita panji adalah menceritakan tentang pertunangan Putra Panji (Inu) dari Kerajaan Jenggala/ Kahuripan dengan Putri Candrakirana (Sekartaji) dari kerajaan Daha/ Kediri. Dua kekasih itu terpisah, kemudian saling mencari sambil berkelana dan mengalami banyak halangan. Akhirnya mereka menyatu 
lagi. Tiga unsur tersebut itu - perpisahan, saling mencari, dan menyatu, adalah ciri khas untuk semua versi cerita Panji (Kieven, 2014c).

Perkembangan berikutnya Kisah Panji banyak direpresentaikan kedalam seni pertunjukan baik tarian (topeng), wayang (beber, gedog, krucil) maupun drama (AndeAnde Lumut, Kethek Ogleng, Arja). Hal ini masih memungkinkan untuk di alihmediakan melalui media lain seperti seni rupa (lukisan, patung, mural) dan juga Film bahkan video game. Sejauh pengamatan penulis baru film "Liku” karya Koes Yuliadi (Koes, 2013) yang mengangkat cerita panji kedalam film dengan Arja sebagai ide dasarnya, kalaupun ada film lain, film tersebut adalah film animasi yang mengangkat cerita turunan dari siklus Panji yaitu Ande-Ande Lumut dan Keong Emas. Berangkat dari hal tersebut penulis ingin mengangkat relief Cerita Panji pada candi menjadi ide dalam penciptaan film, apalagi seperti yang diungkapkan Kieven bahwa cerita panji versi sastra dan relief pada candi memiliki perbedaan. Dari sekian banyak candi yang memiliki relief panji di Jawa Timur, Candi kendalisodo di lereng Penanggungan dipilih sebagai obyek. Diantara candi-candi yang memiliki relief panji di gunung penanggungan, hanya candi kendalisodo yang masih berdiri dan ke empat reliefnya masih bisa terbaca, meskipun terdapat beberapa bagian relief (kepala Panji) sudah hilang (tidak utuh lagi)(Kieven, 2014c).

Selain adanya pembacaan baru tentang Cerita Panji dengan media film, film yang bersifat dokumentatif ini diharapkan membuat masyarakat lebih mengenal dan mencintai kisah asli Indonesia, karena fenomena yang terjadi, masyarakat lebih mengenal Ramayana dan Mahabarata dari pada cerita Panji dan Cerita panji yang terdapat pada relief candi dapat terdokumentasikan.

\section{Tinjauan Pustaka}

Adaptasi merupakan sebuah langkah yang bisa dikatakan mudah, tetapi bisa juga sebaliknya. Hal ini disebabkan karena proses adapatasi haruslah memiliki nilai yang lebih dari sumber-sumbernya. Upaya adaptasi dari satu bentuk menjadi bentuk lain sudah terjadi dan terus berlangsung. Linda Hutcheon, mengatakan dalam bukunya yang berjudul Theory $O f$ Adaptation suatu kesalahan yang besar jika berfikir bahwa adaptasi hanya dapat dilakukan pada novel dan film, apapun bisa diadaptasi, puisi, novel, drama panggung, lukisan, tarian, bahkan video games, apapun bisa dijadikan obyek untuk diadaptasi (Hutcheon, 2006). Richard Krevolin mengatakan bahwa adaptasi adalah proses menangkap esensi sebuah karya asli untuk dituangkan kedalam media lain. Memang tidak bisa dihindari, beberapa elemen akan tetap digunakan dan beberapa lainnya akan ditinggalkan, tapi jiwa cerita itu haruslah tetap sama (2003). Berkaitan dengan apa yang disampaikan Linda, bahwa apapun bisa diadaptasi, maka reliefrelief Cerita Panji yang terdapat pada candi-candi di Jawa Timur akan diadaptasi menjadi film yang bergenre perjalanan (film perjalanan/ Road Movie). Sehingga selain ada cerita naratif yang bersumber dari Cerita Panji yang diadaptasi, diperlihatkan pula unsur dokumentatif dari relief-relief candi tersebut.

Menurut Richard Krevolin adaptasi adalah proses menangkap esensi sebuah karya asli untuk dituangkan kedalam media lain. Memang tidak bisa dihindari, beberapa elemen akan tetap digunakan dan beberapa lainnya akan ditinggalkan, tetapi jiwa cerita itu haruslah tetap sama (2003). Lebih lanjut Krevolin menambahkan, dalam melakukan adaptasi kita memiliki kebebasan dan memiliki beban untuk membuat cerita menjadi lebih menarik. Cerita yang anda tulis harus lebih gamblang, mengalir 
dengan cepat, dan lebih lucu dari pada bahan sumber. Cerita anda harus lebih sarat adegan, lebih mendebarkan hati, dan lebih seksi dari pada cerita aslinya (Krevolin, 2003).

Berdasarkan pengertian di atas maka yang dimaksud dengan adaptasi adalah suatu usaha untuk membuat sebuah hasil karya baru dari sumber yang lainnya atau dari satu media ke media yang lain dengan mempertahankan atau melakukan variasi pada lakuan, tokoh serta gaya dan nada aslinya. Tujuan adaptasi bukanlah untuk mempertahankan sebanyak mungkin kemiripan dengan cerita aslinya, melainkan untuk membuat pilihan terbaik dari materi yang ada untuk menghasilkan skenario sebaik mungkin. Inti dari adaptasi adalah perubahan bentuk, tidak hanya terbatas pada setting, penokohan, alur tapi bisa apapun. Eneste memberikan istilah perubahan bentuk dari novel ke film dengan istilah Ekranisasi. (Eneste, 1989). Ekranisasi adalah pelayar putihan atau pemindahan/pengangkatan sebuah novel kedalam film (ecran dalam bahasa Perancis berarti layar). Pemindahan novel kelayar putih mau tidak mau mengakibatkan timbulnya pelbagai perubahan, oleh Karena itu dapat dikatakan ekranisasi adalah sebuah perubahan. Transformasi (Wibowo, 2012) merupakan perubahan bentuk, rupa dan sifat suatu karya/benda. Adaptasi, Ekranisasi dan Transformasi memiliki pengertian yang sama yaitu perubahan bentuk.

Transformasi bisa juga dikatakan perubahan rupa, bentuk atau sifat suatu karya/benda. Istilah lain yang berdekatan dengan transformasi adalah adaptasi dan saduran. Pada hakikatnya transformasi lebih menekankan pada proses atau metode dalam mengadaptasi/menyadur sebuah karya seni. Maka perubahan bentuk, rupa, dan sifat suatu karya sangat ditentukan oleh metode transformasi yang diterapkan, termasuk transformasi nilai, sehingga perubahan maupun penyesuaian tidak hanya sebatas fisik, tetapi menyangkut perubahan /penyesuaian nilai (spirit). Oleh karena itu isilah transformasi lebih tepat dipakai sebagai metode dalam mengadaptasi atau menyadur suatu karya. Dalam kaitannya transformasi dengan intertekstualitas, melalui Culler Julia Kristeva mengatakan, tidak ada teks yang benar-benar asli tanpa dipengaruhi oleh teks lain. Dalam penyimpangan dan transformasipun model teks yang sudah ada tetap memainkan peranan penting (Ratna, 2011). Oleh karena itulah teks baru memerlukan pemahaman teks-teks yang telah mendahuluinya. Setiap teks merupakan mozaik kutipan yang berasal dari semestaaan yang anonim, penulis hanya menyusunnya. (Ratna, 2011). Maka dalam proses transformasi perlu dilacak lagi teks-teks yang sudah mendahului yang berkaitan dengan topik penciptan.

Penciptaan ini secara khusus bertujuan menciptakan film perjalanan yang ceritanya diadaptasi dari kisah Panji yang terdapat pada relief candi. Selain adanya pembacaan baru tentang Cerita Panji dengan media film, film ini nanti diharapkan membuat masyarakat lebih mengenal dan mencintai kisah asli Indonesia, karena fenomena yang terjadi masyarakat lebih mengenal Ramayana dan Mahabarata dari pada cerita Panji.

Film Perjalanan sangat kuat dengan unsur dokumentatif, maka dengan film ini nantinya ada semacam dokumentasi terhadap relief panji pada candi dalam film tersebut, mengingat seiring perjalanan waktu, semakin banyak relief tersebut yang hilang keseluruhan ataupun pada bagianbagian tertentu.

\section{Metode and Data}

Road movie, merupakan genre film khas amerika dan populer di era klasik. 
Film perjalanan sering bersinggungan dengan genre aksi, drama, serta petualangan. Genre ini biasanya mengisahkan perjalanan darat (umunya mengunakan mobil) jarak jauh dari satu tempat ketempat yang lain, dengan atau tanpa tujuan tertentu. Perjalanan sering kali menjadi tempat pelarian, pencarian, perenungan kehidupan, cinta, kebebasan spiritual serta eksistensi diri. Film perjalanan ini terkesan seperti film dokumenter, karena terkesan dokumentatif (Himawan, 2004). Dalam pemilihan cara bertutur, Film dokumenter memiliki berbagai macam cari bertutur salah satunya berupa laporan perjalanan. Awal kemunculan Film ini hanya ingin mendokumentasikan pengalaman yang didapat selama melakukan perjalanan jauh. Film ini bisa juga disebut dengan travel film, travel documentary, adventure film, ataupun film perjalanan (road movie) (Ayawaila, 2008). Tidak semua road movie adalah dokumenter. Alasannya karena banyak adegan yang tidak berdasarkan apa adanya, karena adegan-adegan itu diciptakan untuk menambah daya tarik film (Ayawaila, 2008) begitiu pula film perjalanan yang akan dibuat merupakan film fiksi bukan film dokumenter.

Esensi dari Road Movie adalah suatu perjalanan yang dilakukan atau dialami tokoh utama untuk mencapai suatu tujuan tertentu, tokoh utama bisa ditemani atau menemani tokoh lain. Berbagai hal (peristiwa) yang dialaminya dalam perjalanan akhirnya memberikan dampak pada tokoh utama. Film road movie memperlihatkan pemandangan yang bagus sepanjang jalan, sutradara biasanya menghadirkan gambar-gambar panorama, lanscaping dengan penataan sinematografi yang baik. Penonton seperti dimanjakan dengan gambar yang indah tentunya tanpa mengurangi esensi cerita.

\section{Hasil dan Pembahasan}

Kisah Panji banyak dipahatkan pada candi -candi Majapahit seperti Candi Mirigambar, Candi Panataran, Candi KendaliSodo, Candi Yudha dan juga candicandi lainnya, baik berbentuk relief fragmen ataupun relief pandunya. Candi Miri Gambar merupakan. bangunan masa majapahit tertua yang dihiasai dengan fragmen cerita panji (Munandar, 2005).

Terdapat tiga ciri pada relief yang menceritakan Kisah Panji. Pertama, pada relief digambarkan dengan tokoh utamanya seorang ksatrya memakai tekes (Topi seperti blangkon Surakarta/Cirebon), memakai kain sebatas lutut atau lebih rendah menutupi tungkai, kadang membawa keris dibagian belakang, tokoh tersebut ialah Raden Panji. Kedua, tokoh Raden Panji selalu disertai pengiring berjumlah 1,2 atau lebih dari dua, apabila berpawakan tinggi besar dan berambut keriting dialah Brajanata/Kertolo dan apabila berpawakan lucu, pendek, gemuk dengan rambut dikuncir keatas dialah Prasanta. Ketiga, ada beberarapa panil juga yang menggambarkan tokoh perempuan muda, yang dimungkinkan adalah kekasih Panji (Dewi Angreni, Martalangu, Sekar Taji atau yang lainnya) dan seorang emban. Ketiga ciri tersebut tidak selalu dijumpai dalam satu pengambaran panil relief Kisah Panji. Bisa jadi ciri satu dan kedua atau ciri satu dan ketiga (Munandar, 2004).

Candi Kendalisodo terletak di lereng utara Gunung Bekel, bukit barat laut dibawah puncak Gunung Penanggungan, Candi Kendalisodo mempunyi tiga teras dengan sebuah tangga yang berada ditengahtengahnya. 


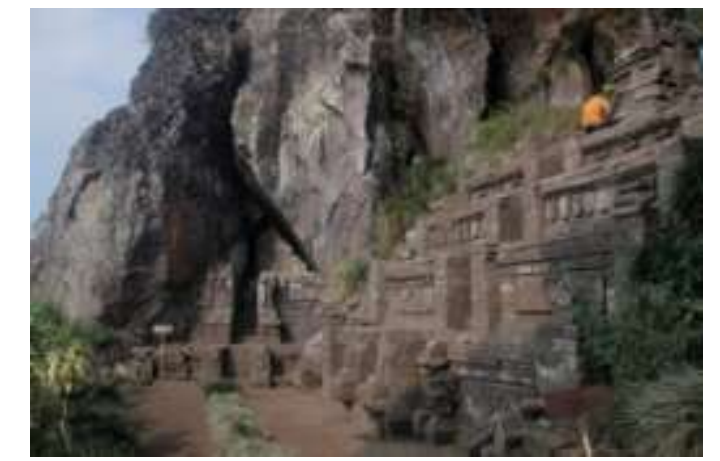

Gambar 1. Candi Kendalisodo dari arah barat Laut (Photo oleh Philipus, 2015)

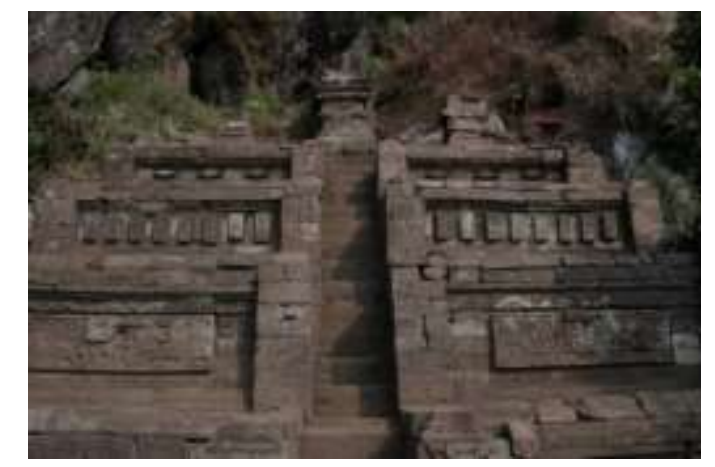

Gambar 2. Candi Kendalisodo dari arah Utara

(Photo oleh Philipus, 2015)

Dua teras bawah dihiasai 4 panel dengan tokoh seorang pria yang menggunaskan tutup kepala (Tekes) dan pasangannya seorang perempuan muda berambut panjang. Pada beberapa panel lain juga menunjukkan kedua tokoh tersebut ditemani perempuan yang mengunakan sanggul dan Punakawan. Laki-laki mengunakan tekes itu adalah Panji seperti yang pernah di sampaikan Kieven sedangkan Perempuan berambut panjang adalah Candrakirana. Perempuan bersanggul dan Punakawan adalah pendamping Panji dan Candrakirana.

Pada Panel pertama menurut pembacaan Kieven (2014c) panel ini menggambarkan Panji dan Candrakirana berada dikompleks yang terdiri dari beberapa bangunan dan dikelilingi tembok, yang mengisyaratkan suasana aristokratis. Dibangunan utama, dua orang digambarkan sedang tidur. Panji dan Candrakirana berlutut menyembah dua orang tidur itu, artinya mereka berpamitan. Menurut Kieven adegan ini terjadi pada malam hari atau pagi-pagi buta, waktu yang dipilih orang Jawa untuk berpergianagar terhindar dari terik Matahari (2014c).

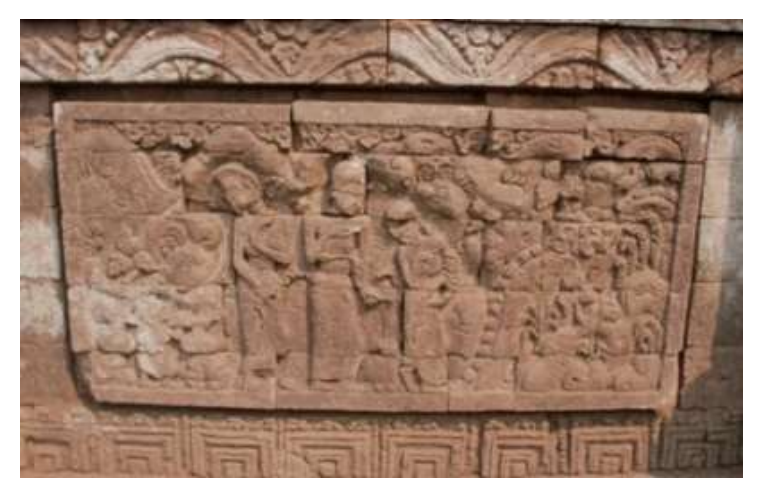

Gambar 3. Panel 1 Candi Kendalisodo (Photo oleh Philipus, 2015)

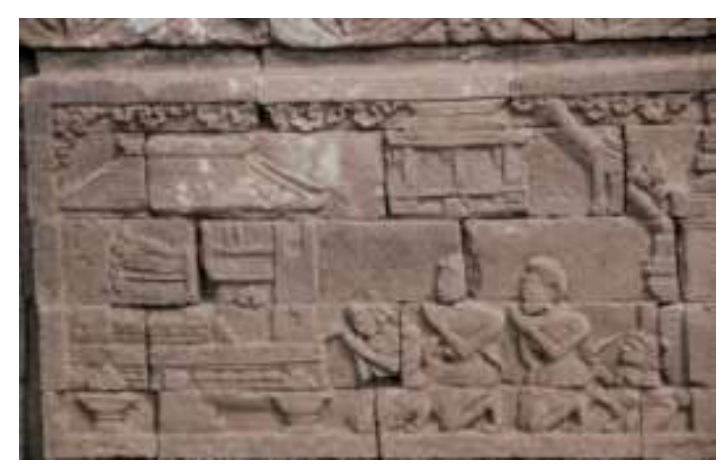

Gambar 4. Panel 2 Candi Kendalisodo (Photo oleh Philipus, 2015)

Panel kedua menurut pembacaan Kieven (2014c) memperlihatkan Panji dan Candrakirana berjalan dialam yang indah yang menampakkan bebatuan, pepohonan dan jalan setapak yang berkelak-kelok melalui pegunungan. Punakawan membawa Wina, alat musik dawai dengan dua resonator yang dihubungkan dengan tangkai seperti yang dikenal di India.

Panel ketiga menurut pembacaan Kieven (2014c) di sisi kanan atas diteras 
kedua menggambarkan Panji memangku Candrakirana sambil memainkan Wina. Mereka berdua tampil dengan sikap tubuh sepasang kekasih yang bercinta. Suasana romantis situasi ini diperkuat dengan penggambaran danau berpancuran tempat mereka beristirahat di tengah perjalanan. Pasangan pelayan digambarkan di kanan bawah, duduk sambil ngobrol.

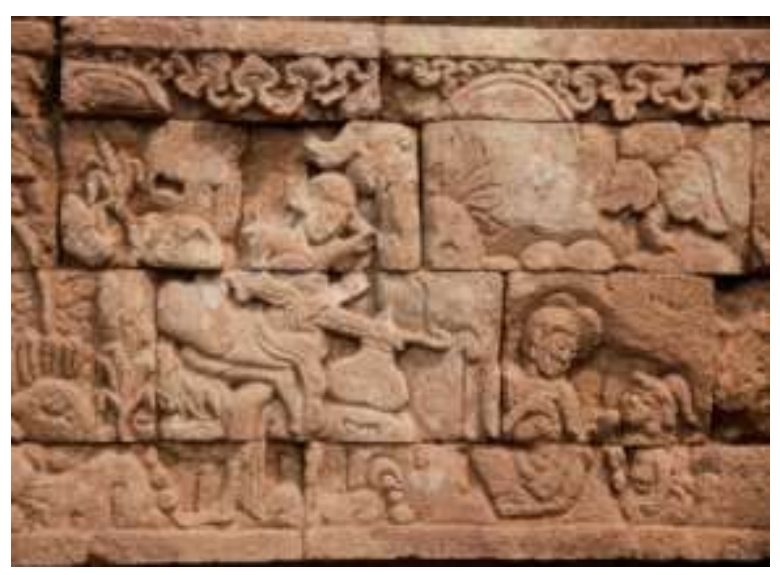

Gambar 5. Panel 3 Candi Kendalisodo (Photo oleh Philipus, 2015)

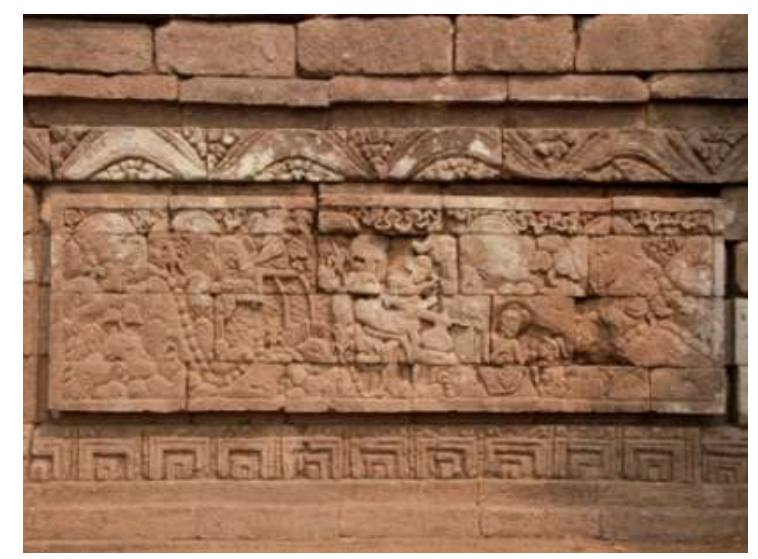

Gambar 6. Detail Panel 3 Candi

Kendalisodo (Photo oleh Philipus, 2015)

Panel keempat menurut pembacaan Kieven (2014c) menggambarkan dibagian kanan, terdapat pemandangan seperti batuan, pepohonan dan jalan setapak, pada bagian kiri terdapat gelombang, kapal yang berlayar dan seekor ikan besar, ini mengindikasikan lautan. Di panti ada pasangan pelayan berlutut, disebelah kanan mereka, berdiri pasangan Panji dan Candrakirana, Panji menoleh pada Candrakirana dan menunjuk kearah lautan dengan tangan kanannya. Seolah sedang menjelaskan sesuatu tentang lautan pada Candrakirana.

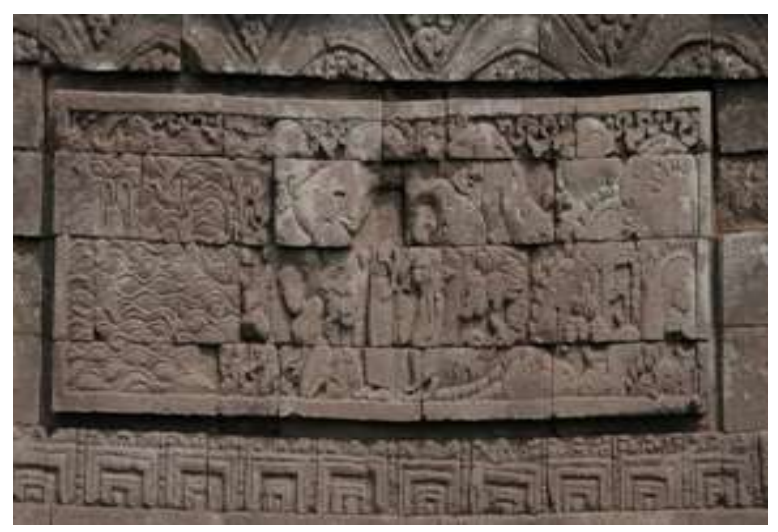

Gambar 7. Panel 4 Candi Kendalisodo

(Photo oleh Philipus, 2015)

Seperti halnya yang disampaikan Kieven bahwa pada relief candi cerita Panji yang di hadirkan, Panji dan Candrakirana bukan digambarkan sebagai prajurit yang sedang berperang melainkaan seperti rakyat biasa yang bersikap sederhana, berkelana di daerah pedesaan, berpakaian sederhana dengan sedikit hiasan saja. Berpijak dari pembacaan Kieven tentang relief candi kendalisodo, tentang pengembaraan Panji dan Candrakirana yang melewati jalanan di alam yang indah dengan bebatuan, pepohonan dan jalan setapak yang berkelakkelok melalui pegunungan hal ini sangat relevan dengan konsep Road Movie yang dipilih. Setelah melakukan pembacaan relief proses selanjutnya adalah mengadaptasi dengan mengaplikasikan konsep Road Movie. Hasil yang didapat berupa Skenario film final draft yang berjudul "Melacak yang Tersurat" yang terdiri dari sinopsis, penokohan, setting dan Film berdurasi sekitar 15 menit berjudul "Melacak yang Tersurat". 


\section{Sinopsis}

Dikisahkan, Kirana adalah seorang mahasiswa yang tinggal di Yogya, ia takjub dengan cerita Tiara sahabatnya tentang kisah Panji yang dipahatkan pada relief. Baru saja Tiara menemui seorang arkeolog dari German bernama Lydia Kieven yang menulis buku tentang figur bertopi pada relief candi Majaphit, yang dalam hipotesa risetnya di asumsikan sebagai Panji.

Ketika mendengar kisah Panji, Kirana merasa ada suatu ikatan yang menariknya untuk tahu lebih jauh tentang cerita Panji, apalagi namanya mirip dengan Candra Kirana. Hal tersebut membuatnya melakukan pelacakan awal beberapa teks cerita Panji. Bahkan ia berencana ingin mengunjungi Candi Kendali Sodo di gunung Penanggungan yang memiliki relief Panji. Sambil ia mencoba meresapi kisah Panji yang kini mulai ia yakini.

Selama perjalanan Kirana ditemani Jo seorang fotografer yang bertubuh agak tambun, penampilannya sangat kekinian tapi senang dengan mobil Volkswagen tua. Ditengah perjalanan, Jo marah. Karena ia baru tahu kalau Kirana sebetulnya mengajaknya pergi ke candi Kendalisodo yang letaknya di Gunung Penanggungan. Jo merasa dibohongi Kirana, ia bermaksud untuk pulang dan tidak meneruskan perjalanan. Kirana bingung meski berbuat apa. Ia tahu kalau ia salah, tapi tak bisa berbuat apa-apa.

Karena Terikat dengan janji, Jo akhirnya tetap mengantarkan Kirana, meskipun ia juga belum pernah pergi ke sana. Jo jadi penasaran, apa sebetulnya yang dicari Kirana di Candi Kendalisodo. Apalagi nampaknya ia juga mulai tertarik dengan sosok Kirana juga kisah Panji yang Kirana ceritakan selama perjalanan. Selama perjalanan hati Kirana makin bergejolak, ia merasa makin yakin bahwa dirinya adalah penjelmaan Candra Kirana yang sedang mengembara untuk menguji kesetiaan Raden
Panji. Tapi siapakah Panji, pada sosok siapakah ia hadir. Jangan-jangan lelaki yang saat ini selalu menemaninya dalam pelacakan ini, atau lelaki-lelaki yang selama ini telah ia temui selama perjalanan hidupnya.

\section{Penokohan}

Pada film ini, terdapat tiga orang tokoh, yaitu Kirana, Jo dan Tiara. Kirana adalah seorang mahasiswi tingkat akhir disalah satu kampus ternama di Yogyakarta. Dibalik wajahnya yang lembut ada pendirian yang kuat dan kokoh. Ia termasuk orang yang keras, ia rela melakukan apapun untuk mewujudkan apa yang ia inginkan. Ia tertarik dengan cerita Panji, ia meyakini bahwa dirinya adalah penjelmaan candra kirana yang sedang mengembara menguji kesetiaan Raden Panji.

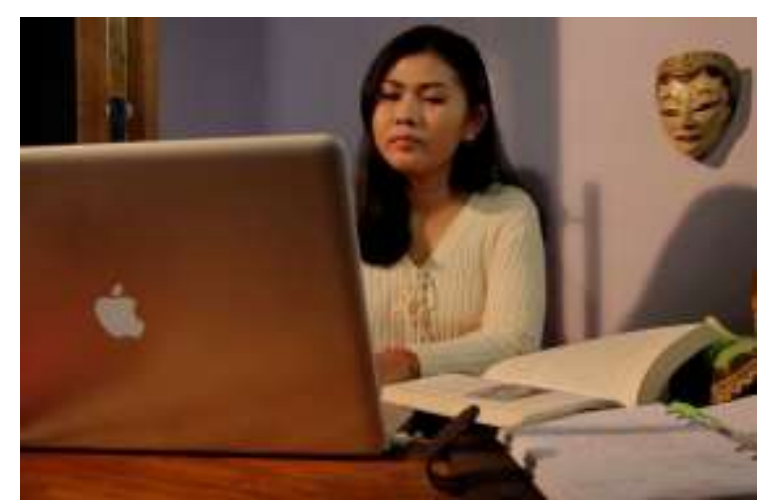

Gambar 8. Kirana

(Photo oleh Philipus, 2015)

Sifat Kirana yang keras dan rela melakukan apapun untuk mewujudkan keinginnannya dapat dilihat dari keinginan Kirana untuk pergi ke Candi Kendalisodo yang ada di gunung penanggungan, Kirana tidak peduli dengan nasehat Tiara, apalagi Kirana belum pernah sekalipun naik gunung. Kirana lebih memilih mengajak Jo untuk mengantarkannya tanpa memberi tahu sebelumnya. Hal ini ia lakukan karena ketertarikannya yang besar untuk melihat relief panji yang ada digunung 
penanggungan. Karakter tersebut dapat dilihat pada skenario scene 03 dan scene 12 .

\section{INT.KAMAR - SIANG \\ Cast : Kirana, Tiara}

Musik pertunjukan masih mengalun dan tidak terputus. Hanya kini tak ada suara music lainnya.

Kirana terlihat sedang merapikan pakaiannya dan segala sesuatu yang akan dibawanya pergi.

Tak jauh dari situ terlihat Tiara sibuk didepan laptopnya. Kini ketika layar laptop terlihat, ada sebuah pertunjukan tari yang menceritakan tentang Panji. Seiring dengan itu musik terdengar lebih keras dan dekat. Sesekali Tiara melirik kearah Kirana kemudian kembali lagi pada laptopnya

\section{TIARA :}

Baru aku tahu.

Ada seorang gadis yang sepertimu..

Kirana acuh, ia masih sibuk dengan aktivitasnya.

\section{TIARA :}

Kamu tidak mengukur antara kemampuan dan keinginan. Antara mimpi dan kenyataan

Kirana masih kukuh dengan acuhnya.

\section{TIARA :}

Yach.. Diam memang pilihan yang paling baik kok.. Aku salut dan angkat topi..

Tanpa berpaling Kirana menjawab

KIRANA :

Kadang rasa itu tidak pernah salah..

Aku yakin dengan apa yang aku rasakan.

Tiara menghela nafasnya

CUT TO

\section{EXT.PINGGIR JALAN}

Cast : Kirana, Jo

JO :

Gila..!! ga waras kamu ya...!!

Jauh-jauh aku antar kamu, ternyata cuma diajak naek gunung..

Gila ini.. aku ga abis pikir.. Kok bisa..
Kenapa ga sejak awal kamu bilang.

KIRANA :

Aku.. Aku takut kamu ga mau antar aku. JO :

Jadi ini, dibalik wajah kalem penampilanmu.

Jo memegang kepalanya.

JO :

Okee.. oke.. lantas kenapa harus aku..

KIRANA :

Aku juga ga tahu...

Aku cuma mengikuti perasaanku..

JO :

Perasaan..?

Ini udah ga jelas.. Cuma buang-buang waktu

KIRANA :

Oke,.. oke...Oke... Denger ya..

Kita memang mau kegunung penaggungan..

JO :

Kita.. ?

KIRANA :

Oke.. tujuanku ke candi kendali sodo.. Letaknya di lereng gunung penanggungan..

Puas... Dan aku juga belum pernah kesana.. jadi aku memang ga tahu apaapa..

Ini memang salahku, aku ga beri tahu kamu sejak awal..

Jo adalah seorang laki-laki yang mengikuti trend zaman, penampilannya nampak kekinian. Badannya agak tambun. Meskipun emosinya sering meluap-luap, ia seorang yang berpegang teguh pada Janji. Ia tertarik dengan sosok Kirana yang begitu terobsesi dengan cerita Panji. Nampaknya ia juga mulai penasaran dengan cerita Panji. Kehadiranya dalam cerita ini bisa dikaitkan sebagai penyamaran Panji yang pergi mengembara. 


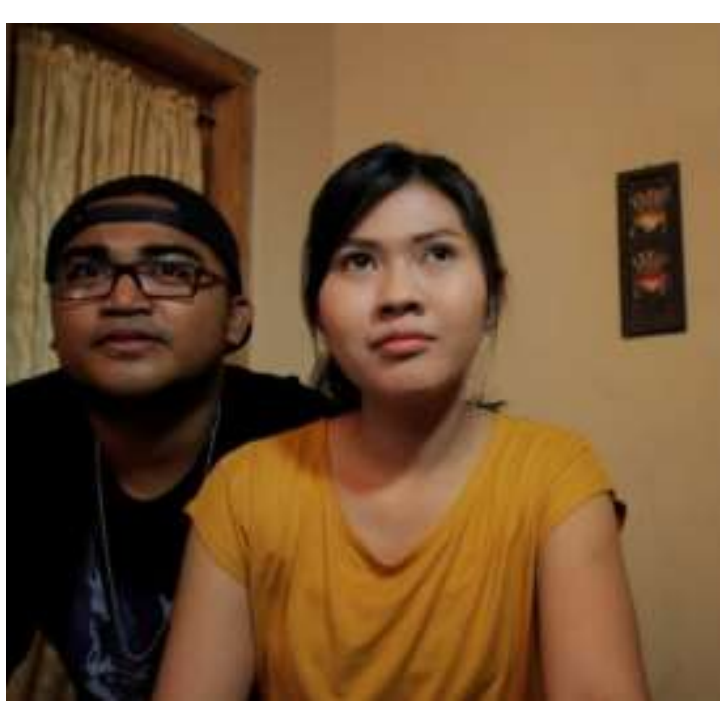

Gambar 9. Jo dan Kirana

(Photo oleh Philipus, 2015)

Karakter Jo yang teguh memegang Janji telihat pada Scene 13:

\section{INT. MOBIL}

Cast: Kirana, Jo

Kirana duduk dikursi, wajahnya masih terlihat bekas menangis. Jo terlihat mengendarai mobil.

Kirana akhirnya berucap

KIRANA: Terima kasih, sudah mau mengantarku.

Jo diam, Kirana kembali tertunduk

KIRANA: Kupikir kamu benar-benar mau mengantarku ke terminal, dan menyuruhku pulang

Jo bicara sekenanya.

JO: Aku sudah janji untuk mengantarmu,

susah untuk mengingkari janji.

KIRANA: Kita belum ada yang pernah kesana, bagaimana kita bisa kesana

JO: Halah.. Kita kan bisa tanya..

Gitu kok repot.. Buat apa GPS.. Hari gini...

Kirana, tersenyum

KIRANA: Terima kasih ya..

Maaf kalau bikin kamu jengkel

Tiara adalah seorang mahasiswa tingkat akhir jurusan arkeologi. Ia tidak menyangka bisa bertemu dengan Lidya Kieven penulis buku Menelusuri Figur
Bertopi dalam Relief Candi Zaman Majapahit, dalam sebuah seminar di museum Ulen Sentanu Yogyakarta. Ia menceritakan pertemuannya dengan Lidya Kieven pada Kirana juga tentang kisah panji lainnya, rupanya ketertarikan Kirana tentang Panji melebihi dirinya.

Ia menasehati kirana untuk mengurungkan niatnya ke gunung Penangungan, apalagi ditemani oleh Jo yang berpawakan tambun. Tapi Kirana nampaknya keras kepala, ia sudah mencoba untuk membujuknya tapi, tak jua berhasil. Karakter Tiara tertuang pada Scene 3 dan 5.

\section{INT. KAMAR - SIANG}

Cast : Kirana, Tiara

Musik pertunjukan masih mengalun dan tidak terputus. Hanya kini tak ada suara music lainnya.

Kirana terlihat sedang merapikan pakaiannya dan segala sesuatu yang akan dibawanya pergi.

Tak jauh dari situ terlihat Tiara sibuk didepan laptopnya. Kini ketika layar laptop terlihat, ada sebuah pertunjukan tari yang menceritakan tentang Panji. Seiring dengan itu musik terdengar lebih keras dan dekat.

Sesekali Tiara melirik kearah Kirana kemudian kembali lagi pada laptopnya

\section{TIARA :}

Baru aku tahu.

Ada seorang gadis yang sepertimu..

Kirana acuh, ia masih sibuk dengan aktivitasnya.

\section{TIARA :}

Kamu tidak mengukur antara kemampuan dan keinginan. Antara mimpi dan kenyataan

Kirana masih kukuh dengan acuhnya.

\section{TIARA :}

Yach.. Diam memang pilihan yang paling baik kok.. Aku salut dan angkat topi..

Tanpa berpaling Kirana menjawab

\section{KIRANA :}

Kadang rasa itu tidak pernah salah.. 
Aku yakin dengan apa yang aku rasakan.

Tiara menghela nafasnya

CUT TO

05. INT. KAMAR - SIANG

Cast : Tiara

Terlihat wajah Tiara yang sedang berbicara pada Kirana. Wajahnya berpaling kearah kanan.

\section{TIARA :}

Bolehlah kamu percaya dengan rasamu, perasaanmu atau apalah..

Tapi ya mesti pilih-pilih kalau ngajak temen...

\section{Setting}

Candi Kendalisodo dan Candi Jolotundo di Gunung Penangungan menjadi setting utama dalam film ini. Sedangkan lokasi-lokasi dalam perjalanan dari Yogya menuju ke Gunung Penanggungan dipilih tempat-tempat yang memang mewakili daerah yang dilewati selama perjalanan, simbol dan tempat-tempat yang indah secara artistik (landscaping).

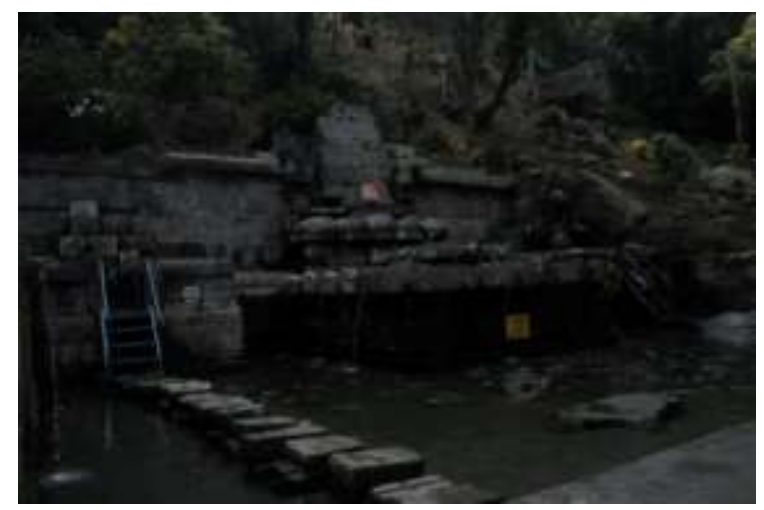

Gambar 10. Candi Jolotundo

(Photo oleh Philipus, 2015)

Film road movie memperlihatkan pemandangan yang bagus sepanjang jalan seperti gambar-gambar panorama, lanscaping dengan penataan sinematografi yang baik.

Gapura Prambanan merupakan batas kota antara Yogyakarta dan Jawa Tengah, lokasi ini dipilih sebagai simbol awal perjalanan, sedangkan Wringin Lawang yang bentuknya menyerupai dengan gapura Prambanan pada adegan terakhir dalam film dipilih sebagai simbol kembali memasuki perjalanan baru. Dimana mereka akan melanjutkan melakukan pelacakan pada candi -candi yang lain. Wringin Lawang dan Gapura Batas Kota Di Prambanan bisa diartikan juga sebagai pintu masuk.

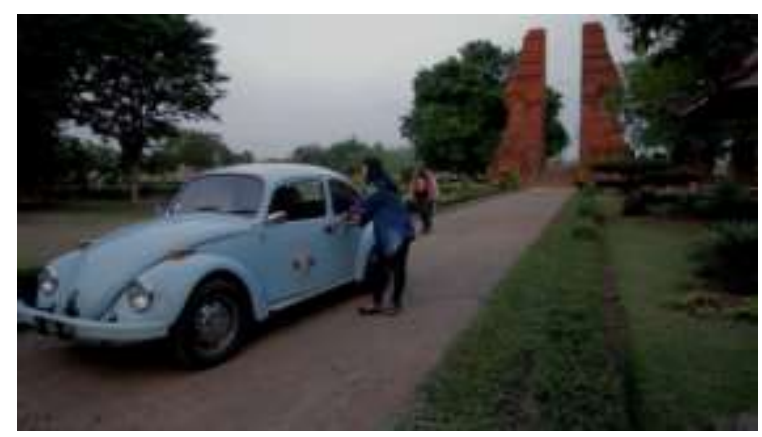

Gambar 11. adegan di Wringin Lawang (Photo oleh Philipus, 2015)

Pabrik Gula Gondang dan jalan-jalan yang artistik merupakan informasi kota yang dilewati, sedangkan Hutan, persawahan, Pohon-pohon cemara, merupakan gambar/tempat yang artistik.

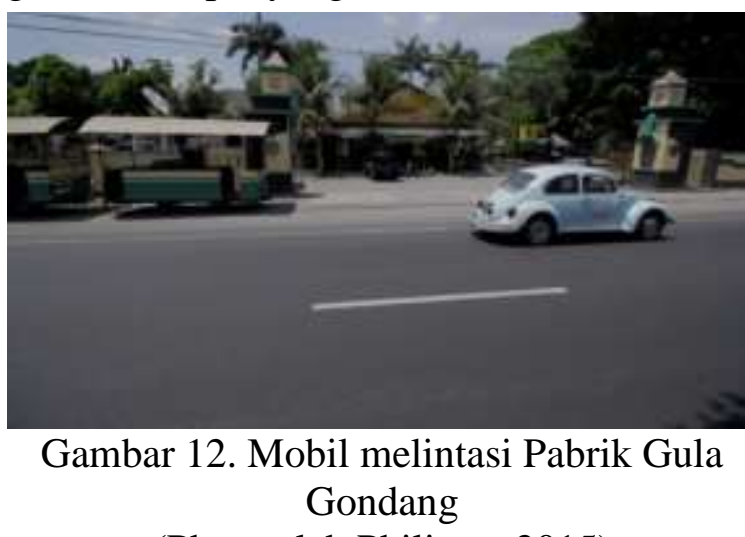

(Photo oleh Philipus, 2015)

\section{Simpulan}

Penciptaan Karya seni yang berjudul Melacak Panji Dalam Relief Sebagai Inspirasi Penciptaan Film telah melalui tahapan-tahapan yang sistematis. Hasil karya akhir berupa Film pendek yang berjudul "Melacak Yang Tersurat" beserta skenario film final draft. Penciptaan film ini 
merupakan salah satu bentuk pembacaan baru tentang kisah Panji dengan media Film, selain itu Penciptaan ini juga diharapkan menumbuhkan kecintaan masyarakat terhadap cerita asli Indonesia. Mengingat masyarakat ternyata lebih mengenal cerita Ramayana dan mahabarata.

Penciptaan ini juga berfungsi sebagai dokumentator relief-relief, mengingat begitu banyaknya relief dan bagian candi lain yang hilang. Hal ini dikarenakan kurangnya kepedulian masyarakat terhadap warisan Budaya dan kurangnya pengawasan terhadap candi yang terletak diatas gunung. Berpijak dari hal tersebut memang sebaiknya perlu adanya penelitian tersendiri untuk melacak relief panji yang sudah hilang oleh disiplin ilmu yang sesuai, mengingat dokumentasi foto tidak terdapat di Indonesia. Pada riset sebelumnya yang dilakukan oleh Lidya Kieven hingga 2010, banyak relief yang sudah tidak utuh lagi. Lidya Kieven mendaptakan dokumentasi foto relief yang masih utuh justru di Belanda. Pada riset yang dilakukan penulis pada tahun 2015 ini ternyata pada panel ke 2 relief terlihat kepala Panji sudah hampir patah.

Proses penciptaan film Road Movie ternyata membutuhkan waktu yang panjang, keseriusan dan kedetailan yang lebih mengingat perjalanan yang dilakukan, merupakan perjalanan yang sesungguhnya yang dilewati tokoh dalam film tersebut. Pengambilan gambar dengan lokasi gunung (gunung Penanggungan) butuh pemilihan talent yang tidak biasa juga persiapan dan kehati-hatian yang ekstra berkaitan dengan medan yang ditempuh.

\section{Daftar Pustaka}

Brandon, J. R. (2003). Jejak-jejak Seni Pertunjukan di Asia Tenggara, terj. Soedarsono, Bandung: P4ST UPI.

Kieven, L. (2014a, Oktober 28-29). Cerita Panji Sebagai Warisan Budaya
Dunia. Seminar dilakukan di Perpustakaan Nasional Republik Indonesia, Jakarta.

Kieven, L. (2014b). Menelusuri Figur Bertopi Dalam Relief Candi Zaman Majapahit, Jakarta: Kepustakaan Populer Gramedia.

Kieven, L. (2014c). Simbolisme Cerita Panji dalam Relief-Relief di Candi Zaman Majapahit dan Nilainya Pada Masa Kini, Prosiding Cerita Panji Sebagai Warisan Budaya Dunia, Seminar Naskah Panji, Jakarta.

Krevolin, R. (2003). Rahasia Sukses Skenario Film-Film Box Offiice, 5 Langkah Jitu Mengadaptasi Apapun Menjadi Skenario Jempolan, Bandung: Mizan Media Utama.

Munandar, A. (2004). Karya Sastra Jawa Kuno yang Diabadikan Pada Relief Candi -Candi Abad ke 13 -15 M. Jurnal Makara, 8(2). 54-60.

Munandar, A. (2005). Tinjauan Ringkas Candi Miri Gambar"dalam Kalajantra: Kumpulan Kajian Arkeologi Hindu- Budha Jawa Timur. Depok: Lab Arkeologi, Program Studi Arkeologi, Fakultas Ilmu Pengetahuan Budaya Universitas Indonesia.

Poerbatjaraka. (1968). Tjerita Panji dalam Perbandingan. Djakarta: Gunung Agung.

Ratna, K. (2011). Teori, Metode, dan Teknik Penelitian Sastra, Yogyakarta: Pustaka pelajar.

Wibowo, P. N. H. (2012) Ande-Ande Lumut; Adaptsi Folklore ke pertunjukan Teater Epik. Thesis

Yuliadi, K. (Director). (2013). Liku [Motion Picture]. Indonesia: Inetra Production. 